Article

\title{
Isolation and Cytotoxicity Evaluation of the Chemical Constituents from Cephalantheropsis gracilis
}

\section{Chi-Fen Chang ${ }^{1}$, Yu-Lin Hsu ${ }^{2}$, Chao-Ying Lee ${ }^{3}$, Chia-Hua Wu ${ }^{3}$, Yang-Chang Wu ${ }^{3,4,5,6,7, *}$ and Ta-Hsien Chuang ${ }^{3,4, *}$}

1 Department of Anatomy, School of Medicine, China Medical University, Taichung 40402, Taiwan; E-Mail: cfchang@mail.cmu.edu.tw

2 Department of Chemistry, National Cheng Kung University, Tainan 70101, Taiwan; E-Mail: lynn4051@yahoo.com.tw

3 School of Pharmacy, China Medical University, Taichung 40402, Taiwan; E-Mails: cylee@mail.cmu.edu.tw (C.-Y.L.); u101003312@cmu.edu.tw (C.-H.W.)

4 Research Center for Chinese Herbal Medicine, China Medical University, Taichung 40402, Taiwan

5 Chinese Medicine Research and Development Center, China Medical University Hospital, Taichung 40402, Taiwan

6 Graduate Institute of Natural Products, Kaohsiung Medical University, Kaohsiung 80708, Taiwan

7 Center of Molecular Medicine, China Medical University Hospital, Taichung 40402, Taiwan

* Authors to whom correspondence should be addressed;

E-Mails: yachwu@mail.cmu.edu.tw (Y.-C.W.); thchuang@mail.cmu.edu.tw (T.-H.C.);

Tel.: +886-4-2205-3366 (ext. 5150) (T.-H.C.); Fax: +886-4-2203-1075 (T.-H.C.).

Academic Editor: Vladimír Křen

Received: 15 January 2015 / Accepted: 2 February 2015 / Published: 12 February 2015

\begin{abstract}
Cephalantheropsis gracilis afforded five new compounds: cephalanthrin-A (1), cephalanthrin-B (2), cephathrene-A (3), cephathrene-B (4), methyl 2-(aminocarbonyl) phenylcarbamate (5), and 52 known compounds. The structures of the new compounds were determined by spectroscopic analysis. Among the compounds isolated, tryptanthrin (6), phaitanthrin A (7), cephalinone D (19), and flavanthrin (30) showed significant cytotoxicity against MCF-7, NCI-H460, and SF-268 cell lines.
\end{abstract}

Keywords: Cephalantheropsis gracilis; Orchidaceae; quinazoline; tryptanthrin; indolotryptanthrin; dihydrophenanthrene; cytotoxicity 


\section{Introduction}

The genus Cephalantheropsis (also known as Cephalanceropsis) belongs to the Orchidaceae family and is comprised of eight species distributed in Southeast Asia. The plant, Cephalantheropsis gracilis (Lindl.) Shiu-Ying Hu var. gracilis, is an orchid native to Taiwan and grows in forests at altitudes of 500-1500 m throughout the island [1]. The crude methanol extract of C. gracilis showed significant cytotoxicity against human breast carcinoma (MCF-7), lung carcinoma (NCI-H460), and central nervous system carcinoma (SF-268) cell lines in our preliminary screening. In earlier papers, the isolation of indole alkaloids was reported from $C$. gracilis, but they are unlikely to be responsible for such anticancer activity [2,3]. In the course of continuing the search for bioactive molecules from C. gracilis, two new quinazolines, cephalanthrin-A (1) and cephalanthrin-B (2), two new dihydrophenanthrenes, cephathrene-A (3) and cephathrene-B (4), and a methyl 2-(aminocarbonyl)phenylcarbamate (5) [4] (Figure 1) as well as 52 known compounds were obtained and identified from a methanol extract (in addition to common long-chain fatty acids, chlorophylls, and steroids). Herein, we describe the structural elucidation of these new compounds and the cytotoxic properties of all compounds identified toward several human cancer cell lines.

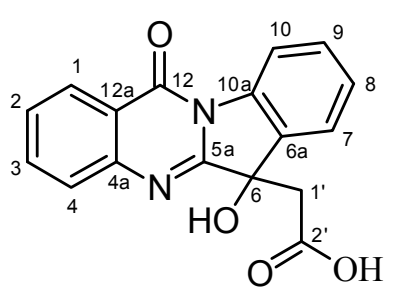

Cephalanthrin A (1)<smiles>[R]c1cc2c(c(OC)c1O)CCc1cc(O)c(O)c(OC)c1-2</smiles>

Cephathrene $A(3): R=H$

Cephathrene $\mathrm{B}(4): \mathrm{R}=\mathrm{OCH}_{3}$<smiles>COC(=O)C1(O)c2ccccc2N=C2C(=O)c3ccccc3N21</smiles>

Cephalanthrin B (2)<smiles>CC(=O)Nc1ccccc1C(N)=O</smiles>

methyl 2-(aminocarbonyl)phenylcarbamate (5)

Figure 1. Structures of five new compounds 1-5.

\section{Results and Discussion}

Cephalanthrin-A (1) was isolated as an optically active white amorphous powder. The molecular formula was determined to be $\mathrm{C}_{17} \mathrm{H}_{12} \mathrm{~N}_{2} \mathrm{O}_{4}$ from a molecular ion of $m / z 308.0794$ by HREIMS. In the IR spectrum, a very broad band at $3000 \mathrm{~cm}^{-1}$ and an absorption band at $1652 \mathrm{~cm}^{-1}$ both indicated the presence of a carboxylic acid. The $1 \mathrm{D}{ }^{1} \mathrm{H}$ and ${ }^{13} \mathrm{C}$ NMR data (Table 1, Figure S1), together with 2D COSY, HMQC, and HMBC spectra, revealed two sets of $o$-disubstituted benzene rings, one at $\delta_{\mathrm{H}} 7.59$ (t, $J=7.5 \mathrm{~Hz}, \mathrm{H}-2), 7.77$ (d, $J=7.5 \mathrm{~Hz}, \mathrm{H}-4), 7.83$ (t, $J=7.5 \mathrm{~Hz}, \mathrm{H}-3$ ), and 8.34 (1H, d, $J=7.5 \mathrm{~Hz}, \mathrm{H}-1$ ); 


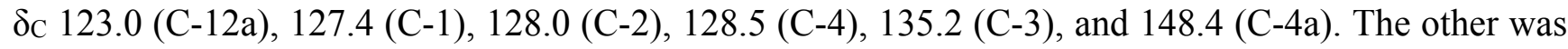
at $\delta_{\mathrm{H}} 7.38(\mathrm{t}, J=7.7 \mathrm{~Hz}, \mathrm{H}-8), 7.51(\mathrm{t}, J=7.7 \mathrm{~Hz}, \mathrm{H}-9), 7.73(1 \mathrm{H}, \mathrm{d}, J=7.7 \mathrm{~Hz}, \mathrm{H}-7)$, and $8.49(1 \mathrm{H}, \mathrm{d}$, $J=7.7$ Hz, H-10); $\delta$ c 117.2 (C-10), 124.6 (C-7), 127.3 (C-8), 130.8 (C-9), 134.2 (C-6a), and 140.8 (C-10a). The ${ }^{13} \mathrm{C}$ NMR data also indicated the presence of an imino C-5a $(\delta 161.9)$ and an amidic C-12 ( $\left.\delta 160.0\right)$. These signals appear to be very closely related to indolo[2,1-b]quinazoline-6,12-dione (tryptanthrin, 6), except that the carbonyl C-6 is replaced by a saturated quaternary carbon $(\delta 75.9)$. NMR spectroscopic data also allowed us to determine the remaining two substituents on $\mathrm{C}-6$ being an $-\mathrm{OH}$ group $(\delta 3.81)$ and a $-\mathrm{CH}_{2} \mathrm{COOH}$ group $\left(\delta_{\mathrm{H}} 3.45,3.55\right.$ (each $\left.1 \mathrm{H}, \mathrm{d}, J=16.5 \mathrm{~Hz}, \mathrm{H}-1^{\prime}\right) ; \delta_{\mathrm{c}} 43.6\left(\mathrm{C}-1^{\prime}\right)$ and 170.9 $\left.\left(\mathrm{C}-2^{\prime}\right)\right)$. The methylene protons adjacent to a quaternary carbon (C-6) could be split due to either chirality or steric hindrance. HMBC correlations from $\mathrm{H}-1$ to $\mathrm{C}-12, \mathrm{H}-7$ to $\mathrm{C}-6$ and $\mathrm{H}-1$ ' to C-5a, C-6 and C-6a, as well as the NOE correlations between $\mathrm{H}-1^{\prime}$ and $\mathrm{H}-7$, supported a structure of 6-hydroxy-6-(carboxymethyl)-tryptanthrin for cephalanthrin-A (1).

Table 1. ${ }^{1} \mathrm{H}$ and ${ }^{13} \mathrm{C}$ NMR Spectroscopic Data and HMBC Correlations for Cephalanthrins $\mathbf{1}$ and 2.

\begin{tabular}{|c|c|c|c|c|c|c|}
\hline \multirow{2}{*}{ Position } & \multicolumn{3}{|c|}{1 in Acetone- $d_{6}(300 \mathrm{MHz} / 75 \mathrm{MHz})$} & \multicolumn{3}{|c|}{2 in $\mathrm{CDCl}_{3}(300 \mathrm{MHz} / 75 \mathrm{MHz})$} \\
\hline & $\delta_{\mathrm{H}}(J$ in $\mathbf{H z})$ & $\boldsymbol{\delta}_{\mathbf{C}}$ & HMBC & $\delta_{\mathrm{H}}(J$ in $\mathrm{Hz})$ & $\boldsymbol{\delta}_{\mathbf{C}}$ & HMBC \\
\hline 1 & $8.34 \mathrm{~d}(7.5)$ & 127.4 & $C-3,-4 a,-12$ & $7.60 \mathrm{~d}(7.6)$ & 126.1 & $C-3,-4 a,-12$ \\
\hline 2 & $7.59 \mathrm{t}(7.5)$ & 128.0 & $C-4,-12 a$ & $7.41 \mathrm{t}(7.6)$ & 129.3 & $\mathrm{C}-4,-12 \mathrm{a}$ \\
\hline 3 & $7.83 \mathrm{t}(7.5)$ & 135.2 & $C-1,-4 a$ & $7.52 \mathrm{t}(7.6)$ & 131.4 & $C-1,-4 a$ \\
\hline 4 & $7.77 \mathrm{~d}(7.5)$ & 128.5 & $C-2,-12 a$ & $7.72 \mathrm{~d}(7.6)$ & 129.7 & $C-2,-12 a$ \\
\hline $4 a$ & & 148.4 & & & 141.9 & \\
\hline $5 \mathrm{a}$ & & 161.9 & & & 144.7 & \\
\hline 6 & & 75.9 & & & 184.0 & \\
\hline $6 a$ & & 134.2 & & & 120.5 & \\
\hline 7 & $7.73 \mathrm{~d}(7.7)$ & 124.6 & C- $6,-9,-10 \mathrm{a}$ & $7.83 \mathrm{~d}(7.6)$ & 125.5 & $C-6,-9,-10 a$ \\
\hline 8 & $7.38 \mathrm{t}(7.7)$ & 127.3 & C-6a, -10 & $7.20 \mathrm{t}(7.6)$ & 124.0 & C-6a, -10 \\
\hline 9 & $7.51 \mathrm{t}(7.7)$ & 130.8 & $C-7,-10 \mathrm{a}$ & 7.59 t (7.6) & 137.9 & $C-7,-10 a$ \\
\hline 10 & 8.49 d (7.7) & 117.2 & C-6a, -8 & $7.23 \mathrm{~d}(7.6)$ & 112.3 & C- $6 a,-8$ \\
\hline $10 \mathrm{a}$ & & 140.8 & & & 148.9 & \\
\hline 12 & & 160.0 & & & 87.4 & \\
\hline $12 \mathrm{a}$ & & 123.0 & & & 120.5 & \\
\hline $1^{\prime}$ & $\begin{array}{l}3.45 \mathrm{~d}(16.5) \\
3.55 \mathrm{~d}(16.5)\end{array}$ & 43.6 & $C-5 a,-6,-6 a,-2^{\prime}$ & & 167.8 & \\
\hline $2^{\prime}$ & & 170.9 & & & & \\
\hline 6-OH & $3.81 \mathrm{~s}$ & & & & & \\
\hline 1'- $\mathrm{OCH}_{3}$ & & & & $3.71 \mathrm{~s}$ & 53.8 & $\mathrm{C}-1^{\prime}$ \\
\hline $12-\mathrm{OCH}_{3}$ & & & & $3.07 \mathrm{~s}$ & 50.6 & $\mathrm{C}-12$ \\
\hline
\end{tabular}

Cephalanthrin-B (2), also isolated as an optically active yellow amorphous powder, was determined to have a molecular formula of $\mathrm{C}_{18} \mathrm{H}_{14} \mathrm{~N}_{2} \mathrm{O}_{4}$. By comparison of the ${ }^{1} \mathrm{H}$ and ${ }^{13} \mathrm{C}$ NMR spectra of 2 (Figure S2) with those of tryptanthrin (6) and cephalanthrin-A (1), an oxygenated quaternary carbon ( $\delta$ 87.4) was shown to replace the carbonyl C-12 to form a 12,12-disubstituted tryptanthrin (Table 1). Methoxyl $\left(\delta_{\mathrm{H}} 3.07 ; \delta_{\mathrm{C}} 50.6\right)$ and methoxycarbonyl $\left(\delta_{\mathrm{H}} 3.71 ; \delta_{\mathrm{C}} 53.8\right.$ and 167.8$)$ substituents were also identified, and their presence was confirmed by HMBC correlations from both $\mathrm{H}-1$ and $12-\mathrm{OCH}_{3}$ to 
C-12 and the NOE correlations between $\mathrm{H}-1, \mathrm{H}-10$ and 1 '- $-\mathrm{OCH}_{3}, 12-\mathrm{OCH}_{3}$. Hence, a structure of 12-methoxy-12-(methoxycarbonyl)-tryptanthrin was deduced for cephalanthrin-B (2). Although compound 2 has been synthesized by Cornforth et al. [5], this represents the first isolation of a pure compound from a natural source.

Due to the small specific rotations of compounds $\mathbf{1}\left([\alpha]_{\mathrm{D}}+8.0^{\circ}\right)$ and $\mathbf{2}\left([\alpha]_{\mathrm{D}}+3.0^{\circ}\right)$, we suspected they might be not optically pure compounds. The configuration of compounds $\mathbf{1}$ and $\mathbf{2}$ has not been determined due to the isolation of insufficient amounts of these materials. However, we adopted the similar structure of phaitanthrin A (7) as a model. First, our attempts to synthesize a pair of diastereomeric esters by acylating 7 with $(+)-\alpha$-methoxy- $\alpha$-trifluoromethylphenylacetyl chloride [(+)-MTPACl] [6], even with acetyl chloride, were unsuccessful. This most likely is due to steric inhibition at the tertiary alcohol, which is present in the tryptanthrin skeleton. We then tried to analyze the C-6 chemical shift behaviors using the chiral shift reagents, tris[3-trifluoroacetyl-D- and L-camphorato]europium(III) [(R)- and $\left.(S)-\mathrm{Eu}(\mathrm{tfc})_{3}\right]$ [7], again to no avail.

Cephathrene-A (3) was isolated as a white amorphous powder with a molecular formula of $\mathrm{C}_{17} \mathrm{H}_{18} \mathrm{O}_{5}$ as determined by the molecular ion peak at $m / z 302.1153$ in HREIMS data. UV absorptions at 267 and $304 \mathrm{~nm}$ indicated the presence of a benzene system, and the IR spectrum revealed an $\mathrm{OH}$ absorption band at $3404 \mathrm{~cm}^{-1}$. From the ${ }^{1} \mathrm{H}$ NMR spectrum, two mutually-coupled aromatic protons at $\delta 6.86(1 \mathrm{H}, \mathrm{d}, J=8.7 \mathrm{~Hz}, \mathrm{H}-6)$ and $7.93(1 \mathrm{H}, \mathrm{d}, J=8.7 \mathrm{~Hz}, \mathrm{H}-5)$ and a proton at $\delta 6.63(1 \mathrm{H}, \mathrm{s}, \mathrm{H}-1)$ suggested the presence of 1,2,3,4-tetrasubstituted and pentasubstituted benzene rings, respectively (Table 2, Figure S3). We also found two mutually coupled aliphatic signals at $\delta 2.66(2 \mathrm{H}, \mathrm{m}, \mathrm{H}-10)$ and $2.79(2 \mathrm{H}, \mathrm{m}, \mathrm{H}-9)$, which were assigned to an ethylene group. HMBC correlations of $\mathrm{H}-9$ with C-4b, C-8, C-8a, C-10, and C-10a, as well as H-10 with C-1, C-4a, C-8a, C-9, and C-10a indicated that the two benzene rings are linked together by the ethylene group. Furthermore, the HMBC correlation between $\mathrm{H}-5$ and C-4a established the existence of a bond between C-4a and C-4b. Thus, compound 3 possessed a 9,10-dihydrophenanthrene skeleton. The HMBC correlations of H-1, H-5, H-6, H-9, and $\mathrm{H}-10$ allowed for the identification of the quaternary aromatic carbons, C-2, C-3, C-4a, C-4b, C-7, C-8, C-8a, and C-10a. We determined the identity of five other substituents, two hydroxyls and three methoxyls. The hydroxyl signal at $\delta 5.65$ showed HMBC correlations with C-6, C-8, and C-7, and the other hydroxyl signal at $\delta 5.70$ showed HMBC correlations with $\mathrm{C}-1, \mathrm{C}-3$, and $\mathrm{C}-2$, indicating that the two hydroxyl groups are attached to $\mathrm{C}-7$ and $\mathrm{C}-2$, respectively. Whereas the three methoxyl signals at $\delta 3.75,3.79$, and 3.96 were shown to be located at C-4, C-8, and C-3, respectively, owing to the $\mathrm{HMBC}$ correlations of $3-\mathrm{OCH}_{3}$ with $\mathrm{C}-3,4-\mathrm{OCH}_{3}$ with $\mathrm{C}-4$, and $8-\mathrm{OCH}_{3}$ with $\mathrm{C}-8$. Additional evidence for the positions of these substituents came from the NOE correlations between 2-OH and $\mathrm{H}-1,3-\mathrm{OCH}_{3}$; H-5 and 4-OCH 3 ; H-1 and $\mathrm{H}-10 ; 8-\mathrm{OCH}_{3}$ and 7-OH, H-9. Therefore, cephathrene-A (3) was assigned the structure 2,7-dihydroxy-3,4,8-trimethoxy-9,10-dihydrophenanthrene.

Cephathrene-B (4) was isolated as a white amorphous powder. The HREIMS showed a molecular ion consistent with the molecular formula $\mathrm{C}_{18} \mathrm{H}_{20} \mathrm{O}_{6}$. The spectral data showed a resemblance to compound 3 (Table 2). The ${ }^{1} \mathrm{H}$ NMR spectrum (Figure S4) disclosed the presence of two singlet aromatic protons at $6.63(\mathrm{H}-1)$ and 7.75 (H-5), indicating a hexasubstituted 9,10-dihydrophenanthrene. The regiochemistries of the substituents, two hydroxyls and four methoxyls, were determined by HMQC, HMBC, and NOESY experiments. As in the case of 3, the two hydroxyls at $\delta 5.59$ and 5.70 are located at C-7 and C-2, respectively, whereas three of the four methoxyls at $\delta 3.75,3.84$, and 3.97 
are at $\mathrm{C}-4, \mathrm{C}-8$, and $\mathrm{C}-3$, respectively. The remaining methoxyl at $\delta 3.93$ was thought to be at $\mathrm{C}-6$ due to NOE correlations between $\mathrm{H}-5$ and 4- and 6-OCH3. Thus, the structure of 2,7-dihydroxy-3,4,6,8tetramethoxy-9,10-dihydrophenanthrene was established for cephathrene-B (4).

Table 2. ${ }^{1} \mathrm{H}$ and ${ }^{13} \mathrm{C}$ NMR Spectroscopic Data and HMBC Correlations for Cephathrenes 3 and 4.

\begin{tabular}{|c|c|c|c|c|c|c|}
\hline \multirow{2}{*}{ Position } & \multicolumn{3}{|c|}{3 in $\mathrm{CDCl}_{3}(400 \mathrm{MHz} / 100 \mathrm{MHz})$} & \multicolumn{3}{|c|}{4 in $\mathrm{CDCl}_{3}(300 \mathrm{MHz} / 75 \mathrm{MHz})$} \\
\hline & $\delta_{\mathrm{H}}(J$ in $\mathrm{Hz})$ & $\boldsymbol{\delta}_{\mathbf{C}}$ & НMBC & $\delta_{\mathrm{H}}(J$ in $\mathrm{Hz})$ & $\delta_{\mathbf{C}}$ & НMBC \\
\hline 1 & $6.63 \mathrm{~s}$ & 109.9 & $C-2,-3,-4 a,-10$ & $6.63 \mathrm{~s}$ & 110.1 & $C-2,-3,-4 a,-10$ \\
\hline 2 & & 147.6 & & & 147.7 & \\
\hline 3 & & 139.0 & & & 139.0 & \\
\hline 4 & & 150.5 & & & 150.4 & \\
\hline $4 a$ & & 120.3 & & & 120.3 & \\
\hline $4 \mathrm{~b}$ & & 125.9 & & & $124.2 *$ & \\
\hline 5 & $7.93 \mathrm{~d}(8.7)$ & 124.2 & $C-4 a,-7,-8 a$ & $7.75 \mathrm{~s}$ & 106.6 & $C-4 a,-4 b,-6,-7,-8 a$ \\
\hline 6 & $6.86 \mathrm{~d}(8.7)$ & 112.8 & $\mathrm{C}-4 \mathrm{~b},-8$ & & 145.5 & \\
\hline 7 & & 147.1 & & & 137.1 & \\
\hline 8 & & 143.6 & & & 143.7 & \\
\hline $8 \mathrm{a}$ & & 130.8 & & & $124.3 *$ & \\
\hline 9 & $2.79 \mathrm{~m}$ & 22.4 & $C-4 b,-8,-8 a,-10,-10 a$ & $2.73 \mathrm{~m}$ & 21.5 & $C-4 b,-8,-10,-10 a$ \\
\hline 10 & $2.66 \mathrm{~m}$ & 29.5 & $C-1,-4 a,-8 a,-9,-10 a$ & $2.64 \mathrm{~m}$ & 29.8 & $C-1,-4 a,-8 a,-9$ \\
\hline $10 \mathrm{a}$ & & 134.5 & & & 135.2 & \\
\hline $2-\mathrm{OH}$ & $5.70 \mathrm{~s}$ & & $C-1,-2,-3$ & $5.70 \mathrm{~s}$ & & \\
\hline $3-\mathrm{OCH}_{3}$ & $3.96 \mathrm{~s}$ & 61.1 & C-3 & $3.97 \mathrm{~s}$ & 61.2 & $\mathrm{C}-3$ \\
\hline $4-\mathrm{OCH}_{3}$ & $3.75 \mathrm{~s}$ & 60.1 & C-4 & $3.75 \mathrm{~s}$ & 60.1 & C-4 \\
\hline $6-\mathrm{OCH}_{3}$ & & & & $3.93 \mathrm{~s}$ & 56.3 & C-6 \\
\hline 7-OH & $5.65 \mathrm{~s}$ & & $C-6,-7,-8$ & $5.59 \mathrm{~s}$ & & \\
\hline $8-\mathrm{OCH}_{3}$ & $3.79 \mathrm{~s}$ & 61.3 & C-8 & $3.84 \mathrm{~s}$ & 60.8 & C-8 \\
\hline
\end{tabular}

* Assignments may be interchangeable.

Compound 5, with molecular formula $\mathrm{C}_{9} \mathrm{H}_{10} \mathrm{~N}_{2} \mathrm{O}_{3}$, was isolated as a white amorphous powder. It had UV absorptions at 257, 289, and $311 \mathrm{~nm}$, indicative of an aromatic system. The ${ }^{1} \mathrm{H}$ NMR spectrum (Figure S5) showed resonances at $\delta 7.05(1 \mathrm{H}, \mathrm{t}, J=7.8 \mathrm{~Hz}, \mathrm{H}-4), 7.49(1 \mathrm{H}, \mathrm{t}, J=7.8 \mathrm{~Hz}, \mathrm{H}-5)$, $7.83(1 \mathrm{H}, \mathrm{d}, J=7.8 \mathrm{~Hz}, \mathrm{H}-3)$, and $8.38(1 \mathrm{H}, \mathrm{d}, J=7.8 \mathrm{~Hz}, \mathrm{H}-6)$ for an $o$-disubstituted benzene. The HMBC correlations from $\mathrm{H}-3$ to an amide carbon $\left(\delta\right.$ 172.0) and from $\mathrm{OCH}_{3}(\delta 3.71)$ to a carbamate carbon $(\delta$ 154.6) and the NOE correlation between $\mathrm{H}-6$ and an amine proton $(\delta 11.29)$ suggested the structure of methyl 2-(aminocarbonyl)phenylcarbamate for $\mathbf{5}$. The ${ }^{1} \mathrm{H}$ and ${ }^{13} \mathrm{C}$ NMR spectra of 5 and the acylation product of $o$-aminobenzamide with methyl chloroformate $\left(\mathrm{ClCO}_{2} \mathrm{CH}_{3}\right)$ were identical and further confirmed the structure of $\mathbf{5}$ (Equation (1)).

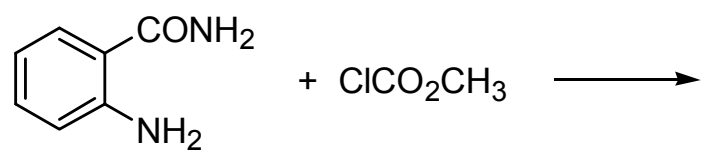<smiles>CC(=O)Nc1ccccc1C(N)=O</smiles>

5

Other known compounds were also isolated from C. grilis including 7 quinazolines, tryptanthrin (6) [8], phaitanthrin A (7) [8], phaitanthrin B (8) [8], methylisatoid (9) [8], candidine (10) [8], 
1H-quinazoline-2,4-dione (11) [9], and 3-(2-hydroxy-phenyl)-3H-quinazolin-4-one (12) [10]; 15 indole alkaloids, cephalandole A (13) [2], cephalandole B (14) [2], cephalandole C (15) [2], cephalinone A (16) [2], cephalinone B (17) [2], cephalinone C (18) [2], cephalinone D (19) [2], (S)-3-(2-oxopropyl)-3-hydroxyindolin-2-one (20) [2], methyl dioxindole-3-acetate (21) [2], isatan (22) [2], indigo (23) [2], indirubin (24) [2], isatin (25) [2], indole-3-carbaldehyde (26) [2], and indole-3-carboxylic acid (27) [2]; 2 indolotryptanthrins cephathrindole A (28) [3] and cephathrindole B (29) [3]; 5 dihydrophenanthrenes, flavanthrin (30) [11], coelonin (31) [11], 6-O-methylcoelonin (32) [12], 2,7-dihydroxy-3,4-dimethoxy-9,10-dihydrophenanthrene (33) [13], and 2,7-dihydroxy-3,4,6trimethoxy-9,10-dihydrophenanthrene (34) [11]; 1 lignin, secoisolariciresinol (35) [14]; 1 flavonoid, kaempferol 3-rutinoside (36) [15]; 1 ionol, blumenol A (37) [16]; and 20 benzenoids, 2-aminobenzoic acid (38), methyl 2-aminobenzoate (39), $N$-cinnamoyltyramine (40), $N$-p-coumaroyltyramine (41), $N$-trans-feruloyltyramine (42), dihydroconiferyl dihydro- $p$-coumarate (43), 4-hydroxybenzaldehyde (44), 1-(4-hydroxy-phenyl)ethanone (45), 4-hydroxy-phenethyl alcohol (46), 3-(4-hydroxy-phenyl)-propionic acid (47), vanillin (48), vanillic acid (49), 4-hydroxy-3-methoxybenzyl alcohol (50), syringaldehyde (51), 3,5-dimethyl-4-hydroxypropiophenone (52), trans-p-coumaric acid (53), trans-ferulic acid (54), cis-ferulic acid (55), methyl trans-4-hydroxy-3-methoxycinnamate (56), and methylsinapat (57).

All the isolated compounds were subjected to cytotoxic evaluation against MCF-7, NCI-H460, and SF-268 cell lines. Tryptanthrin (6), phaitanthrin A (7), cephalinone D (19), and flavanthrin (30) showed significant cytotoxicity against MCF-7, NCI-H460, and SF-268 cell lines with $\mathrm{IC}_{50}$ values of 7.6-42.9 $\mu \mathrm{M}$ (Table 3).

Table 3. Cytotoxicity of active compounds toward three cancer lines.

\begin{tabular}{cccc}
\hline \multirow{2}{*}{ Compound } & \multicolumn{3}{c}{$\mathbf{I C}_{\mathbf{5 0}}(\boldsymbol{\mu M})$} \\
\cline { 2 - 4 } & $\mathbf{M C F}-\mathbf{7}$ & $\mathbf{N C I}-\mathbf{H 4 6 0}$ & $\mathbf{S F - 2 6 8}$ \\
\hline Tryptanthrin (6) & $9.4 \pm 0.3$ & $8.5 \pm 0.8$ & $22.6 \pm 1.1$ \\
Phaitanthrin A (7) & $17.8 \pm 0.8$ & $17.3 \pm 1.2$ & $42.9 \pm 1.0$ \\
Cephalinone D (19) & $7.6 \pm 0.7$ & $7.8 \pm 1.0$ & $12.2 \pm 1.3$ \\
Flavanthrin (30) & $21.9 \pm 1.5$ & $22.8 \pm 2.3$ & $23.0 \pm 2.0$ \\
\hline
\end{tabular}

Values were mean $\pm \mathrm{SD}(n=3-8)$; MCF-7 = human breast tumor cell line; NCI-H460 = human lung tumor cell line; SF-268 = human entral nervous system tumor cell line.

\section{Experimental Section}

\subsection{General}

Optical rotations were measured on a Jasco DIP-370 digital polarimeter (JASCO, Tokyo, Japan). UV spectra were recorded on an Agilent 8453 spectrophotometer (Agilent Technologies, Palo Alto, CA, USA). IR spectra were recorded on a Nicolet Magna FT-IR spectrophotometer (Nicolet Instrument, Inc., Madison, WI, USA). NMR spectra were recorded on a Bruker Avance 300 (Bruker, Karlsruhe, Germany) and AMX 400 spectrometers (Bruker, Karlsruhe, Germany), and all chemical shifts are given in ppm using tetramethylsilane $(\delta 0.00)$ as an internal standard. Mass spectra were obtained on a VG 70-250S spectrometer by a direct inlet system (Micromass Corp., Manchester, UK). 


\subsection{Plant Material}

Whole Cephalantheropsis gracilis plants were collected from Pingtung Hsien, Taiwan, in December 2004, as authenticated by Chang-Sheng Kuoh, Department of Biology, National Cheng Kung University, Tainan, Taiwan. A voucher specimen (No: PLW-0401) was deposited in the Herbarium of National Cheng Kung University, Tainan, Taiwan.

\subsection{Extraction and Isolation}

The dried aerial parts of $C$. gracilis $(2.4 \mathrm{~kg})$ were extracted with $\mathrm{MeOH}(8 \mathrm{~L})$ under reflux 8 times. The combined extracts were concentrated under reduced pressure to produce a dark brown syrup. The syrup was then suspended in $\mathrm{H}_{2} \mathrm{O}$ and then partitioned with hexane, $\mathrm{CHCl}_{3}$, and EtOAc, successively. The concentrated hexane layer (47 g) was chromatographed on a silica gel column by eluting with a gradient of hexane- $\mathrm{Me}_{2} \mathrm{CO}\left(10: 1\right.$ to pure $\left.\mathrm{Me}_{2} \mathrm{CO}\right)$ to give six fractions. Fraction 3 was chromatographed on silica gel by elution with hexane- $i-\operatorname{Pr}_{2} \mathrm{O}\left(1: 3\right.$ to pure $\left.i-\operatorname{Pr}_{2} \mathrm{O}\right)$ to give $48(9.6 \mathrm{mg})$. Fraction 4 was chromatographed on silica gel using the same solvent mixture to yield 3 (4.3 $\mathrm{mg}$ ), $34(7.0 \mathrm{mg}), \mathbf{5 2}(0.7 \mathrm{mg})$, and $\mathbf{5 7}(1.4 \mathrm{mg})$. Fraction 5 was chromatographed on silica gel eluting with $i-\mathrm{Pr}_{2} \mathrm{O}$ (pure $i-\mathrm{Pr}_{2} \mathrm{O}$ to $30: 1$ of $i-\mathrm{Pr}_{2} \mathrm{O}-\mathrm{Me}_{2} \mathrm{CO}$ to pure $\mathrm{Me}_{2} \mathrm{CO}$ ) to give 4 (6.6 mg), 32 (3.5 mg), and 29 (5 mg).

The $\mathrm{CHCl}_{3}$ extract (30 g) was chromatographed on a silica gel column by eluting with a gradient of hexane- $\mathrm{Me}_{2} \mathrm{CO}$ (1:2 to pure $\left.\mathrm{Me}_{2} \mathrm{CO}\right)$ to yield twelve fractions. Fraction 1 was subjected to chromatography on a silica gel column eluting with a gradient of hexane- $\mathrm{Me}_{2} \mathrm{CO}$ (10:1 to pure $\left.\mathrm{Me}_{2} \mathrm{CO}\right)$ to give $\mathbf{1 0}(61.8 \mathrm{mg})$ and $\mathbf{3 9}(2.2 \mathrm{mg})$. Fraction 2 was chromatographed on a silica gel column eluting with a gradient of hexane- $\mathrm{Me}_{2} \mathrm{CO}\left(6: 1\right.$ to pure $\left.\mathrm{Me}_{2} \mathrm{CO}\right)$ to give 7 (39.4 mg), 2 (3.6 mg), $\mathbf{6}(543.1 \mathrm{mg}), \mathbf{1 3}(8.6 \mathrm{mg})$, and $\mathbf{1 7}(5.8 \mathrm{mg})$. Similarly, fraction 3 was chromatographed with a gradient of hexane- $\mathrm{Me}_{2} \mathrm{CO}\left(4: 1\right.$ to pure $\left.\mathrm{Me}_{2} \mathrm{CO}\right)$ to give $\mathbf{5 1}(2.2 \mathrm{mg})$ and $\mathbf{5 6}(22.7 \mathrm{mg})$. Fraction 5 was subjected to chromatography over silica gel eluting with a gradient of hexane- $i-\operatorname{Pr}_{2} \mathrm{O}\left(1: 4\right.$ to pure $\left.i-\operatorname{Pr}_{2} \mathrm{O}\right)$ to give $14(20.0 \mathrm{mg})$ and $24(48.0 \mathrm{mg})$. Fraction 6 was further purifed on a silica gel column eluting with a gradient of $i-\mathrm{Pr}_{2} \mathrm{O}-\mathrm{MeOH}(50: 1$ to pure $\mathrm{MeOH})$ to give $9(34.4 \mathrm{mg}), 19$ (30.0 mg), and 28 (12 mg). Fraction 7 was chromatographed on a silica gel column eluting with a gradient of hexane- $\mathrm{CHCl}_{3}$ (6:1 to pure $\left.\mathrm{CHCl}_{3}\right)$ to give $25(62.1 \mathrm{mg}), \mathbf{3 3}(0.7 \mathrm{mg}), \mathbf{5}(2.9 \mathrm{mg}), \mathbf{4 3}(11.4 \mathrm{mg}), \mathbf{4 4}(8 \mathrm{mg})$, and $45(1.6 \mathrm{mg})$. Fraction 8 was subjected to chromatography over silica gel eluting with a gradient of $\mathrm{CHCl}_{3}-\mathrm{Me}_{2} \mathrm{CO}\left(30: 1\right.$ to pure $\left.\mathrm{Me}_{2} \mathrm{CO}\right)$ to give $12(50.4 \mathrm{mg}), 26(2.7 \mathrm{mg}), 31$ (39.5 mg), 40 (3.4 mg), and $50(8.3 \mathrm{mg})$. Fraction 9 was further chromatographed on a silica gel column eluting with a gradient of hexane-EtOAc (15:1 to pure EtOAc) to give $\mathbf{1 1}(54.1 \mathrm{mg})$ and $\mathbf{1 8}(6.2 \mathrm{mg})$. Fraction 10 was chromatographed on a silica gel column eluting with a gradient of $i$ - $\mathrm{Pr}_{2} \mathrm{O}-\mathrm{MeOH}(9: 1$ to pure $\mathrm{MeOH})$ to give 27 (2.2 mg), 35 (2.3 mg), 42 (103 mg), 46 (1.2 mg), 49 (33.3 mg), and 37 (5.1 mg). Finally, fraction 11 was chromatographed on a silica gel column eluting with a gradient of $\mathrm{CHCl}_{3}-\mathrm{MeOH}(10: 1$ to pure $\mathrm{MeOH})$ to give $\mathbf{5 3}(2.1 \mathrm{mg}), \mathbf{5 4}(37.4 \mathrm{mg}), \mathbf{5 5}(5.4 \mathrm{mg})$, and Fraction 12 yielded 23 (328.2 $\mathrm{mg})$ as a pure crystalline material.

The EtOAc extract ( $20 \mathrm{~g}$ ) was subjected to column chromatography using Cosmosil $75 \mathrm{C} 18$ and eluted with a gradient of $\mathrm{H}_{2} \mathrm{O}-\mathrm{MeOH}$ (from pure $\mathrm{H}_{2} \mathrm{O}$ to pure $\mathrm{MeOH}$ ) to give nine fractions. Fraction 2 
was subjected to further chromatography on a Cosmosil $75 \mathrm{C} 18$ column eluting with a gradient of $\mathrm{H}_{2} \mathrm{O}-\mathrm{MeOH}$ (from pure $\mathrm{H}_{2} \mathrm{O}$ to pure $\mathrm{MeOH}$ ) to give $21(3.6 \mathrm{mg}$ ) and 47 (12.5 mg). Fraction 3 was chromatographed on a silica gel column eluting with a gradient of $i-\mathrm{Pr}_{2} \mathrm{O}-\mathrm{MeOH}(15: 1$ to pure $\mathrm{MeOH})$ to give $22(2.2 \mathrm{mg})$. Fraction 4 was subjected to repeated chromatography on a silica gel column eluting with a gradient of $i-\mathrm{Pr}_{2} \mathrm{O}-\mathrm{MeOH}(10: 1$ to pure $\mathrm{MeOH})$ to give $\mathbf{1}(1.4 \mathrm{mg}), \mathbf{1 6}(3.5 \mathrm{mg})$, 36 (12.6 mg), and 41 (44.5 mg). Fraction 5 was chromatographed on a silica gel column eluting with a gradient of $i-\mathrm{Pr}_{2} \mathrm{O}-\mathrm{MeOH}(20: 1$ to pure $\mathrm{MeOH})$ to give $\mathbf{8}(9.8 \mathrm{mg}), 15(22.2 \mathrm{mg})$, and $38(2.9 \mathrm{mg})$. Fraction 6 was further purified over silica gel eluting with a gradient of $\mathrm{CHCl}_{3}-\mathrm{MeOH}(15: 1$ to pure $\mathrm{MeOH})$ to give $20(20.9 \mathrm{mg})$. Fraction 7 was further chromatographed on a silica gel column eluting with a gradient of $i-\mathrm{Pr}_{2} \mathrm{O}-\mathrm{MeOH}(8: 1$ to pure $\mathrm{MeOH})$ to give $30(4.0 \mathrm{mg})$.

Cephalanthrin-A (1). White amorphous powder, mp $212-214{ }^{\circ} \mathrm{C} ;[\alpha]_{\mathrm{D}}+8.0^{\circ}$ (c $0.07, \mathrm{CH}_{3} \mathrm{OH}$ ); UV $\lambda_{\max }(\log \varepsilon) \mathrm{CH}_{3} \mathrm{OH} 206$ (4.0), 261 (3.3), 302 (3.0), 314 (3.1), 329 (3.0) nm; IR v $v_{\max }$ (KBr) 3000 (br), 1652, $1464 \mathrm{~cm}^{-1}$; EIMS m/z (rel. int.) $308\left(\mathrm{M}^{+}, 13\right), 250$ (100), 219 (8), 119 (19); HREIMS m/z 308.0794 [M] $]^{+}$(Calcd for $\left.\mathrm{C}_{17} \mathrm{H}_{12} \mathrm{~N}_{2} \mathrm{O}_{4}, 308.0797\right)$.

Cephalanthrin-B (2). Yellow amorphous powder, mp 215-217 ${ }^{\circ} \mathrm{C}$; $[\alpha]_{\mathrm{D}}+3.0^{\circ}$ (c $0.11, \mathrm{CHCl}_{3}$ ); UV $\lambda_{\max }(\log \varepsilon) \mathrm{CHCl}_{3} 259$ (3.2), 276 (3.0), 316 (2.9), 442 (2.9) nm; IR $v_{\max }(\mathrm{KBr})$ 1754, 1722, 1643, 1607, $1592 \mathrm{~cm}^{-1}$; EIMS m/z (rel. int.) $322\left(\mathrm{M}^{+}, 2\right), 291$ (5), 263 (100); HREIMS m/z 322.0955 [M] $]^{+}$ (Calcd For $\mathrm{C}_{18} \mathrm{H}_{14} \mathrm{~N}_{2} \mathrm{O}_{4}, 322.0953$ ).

Cephathrene-A (3). White amorphous powder, mp 96-98 ${ }^{\circ} \mathrm{C}$; UV $\lambda_{\max }(\log \varepsilon) \mathrm{CHCl}_{3} 267$ (3.3),

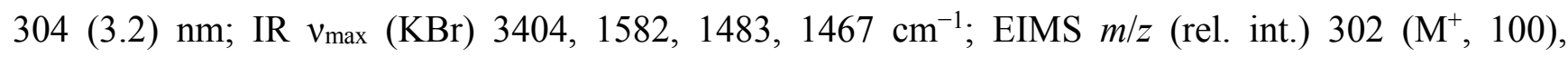
255 (35), 184 (10); HREIMS $m / z 302.1153$ [M] $]^{+}$(Calcd for $\mathrm{C}_{17} \mathrm{H}_{18} \mathrm{O}$, 302.1154).

Cephathrene-B (4). White amorphous powder; UV $\lambda_{\max }(\log \varepsilon) \mathrm{CHCl}_{3}$ : 265 (3.2), 316 (3.0) nm; IR $v_{\max }(\mathrm{KBr}) 3400,1606,1501,1464 \mathrm{~cm}^{-1}$; EIMS m/z (rel. int.) 332 (M+2, 20), 331 (100), 302 (24), 285 (17); HREIMS $m / z 332.1262[\mathrm{M}]^{+}$(Calcd For $\mathrm{C}_{18} \mathrm{H}_{20} \mathrm{O}_{6}, 332.1260$ ).

Methyl 2-(Aminocarbonyl)phenylcarbamate (5). White amorphous powder, mp 200-202 ${ }^{\circ} \mathrm{C}$; UV $\lambda_{\max }(\log \varepsilon) \mathrm{CH}_{3} \mathrm{OH} 212$ (2.9), 228 (3.0), 257 (2.9), 289 (2.7), 311 (2.7) nm; IR $v_{\max }(\mathrm{KBr}) 3417$, $3211,1726,1686,1626,1598,1531 \mathrm{~cm}^{-1} ;{ }^{1} \mathrm{H}$ NMR (acetone- $\left.d_{6}\right) \delta 3.71\left(3 \mathrm{H}, \mathrm{s}, \mathrm{OCH}_{3}\right), 6.99$ and 7.74 (each 1H, br s, NH2), $7.05(1 \mathrm{H}, \mathrm{t}, J=7.8 \mathrm{~Hz}, \mathrm{H}-4), 7.49(1 \mathrm{H}, \mathrm{t}, J=7.8 \mathrm{~Hz}, \mathrm{H}-5), 7.83(1 \mathrm{H}, \mathrm{d}, J=7.8 \mathrm{~Hz}$, $\mathrm{H}-3), 8.38(1 \mathrm{H}, \mathrm{d}, J=7.8 \mathrm{~Hz}, \mathrm{H}-6), 11.29(1 \mathrm{H}$, br s, $1-\mathrm{NH}) ;{ }^{13} \mathrm{C}$ NMR (acetone- $\left.d_{6}\right) \delta 52.2\left(\mathrm{OCH}_{3}\right)$, 119.2 (C-2), 119.6 (C-6), 122.2 (C-4), 129.1 (C-3), 133.4 (C-5), 141.7 (C-1), 154.6 (NC=O), 172.0 (2-C=O); EIMS m/z (rel. int.) $194\left(\mathrm{M}^{+}, 31\right), 162$ (32), 146 (100), 118 (9); HREIMS m/z 194.0693 [M] $]^{+}$ (calcd for $\mathrm{C}_{9} \mathrm{H}_{10} \mathrm{~N}_{2} \mathrm{O}_{3}, 194.0692$ ).

\subsection{Cytotoxicity Assay}

The cytotoxicity assay was carried out according to the procedure described in the literature [17].

\section{Conclusions}

Five new compounds, cephalanthrin-A (1), cephalanthrin-B (2), cephathrene-A (3), cephathrene-B (4), methyl 2-(aminocarbonyl)phenylcarbamate (5), and 52 known compounds were isolated from 
Cephalantheropsis gracilis. Cephalinone D (19) showed the strongest cytotoxicity against the tested tumor cell lines, with $\mathrm{IC}_{50}$ values ranging from 7.6 to $42.9 \mu \mathrm{M}$. The modifications using Cephalinone $\mathrm{D}$ as template are being studied in our laboratories, aiming to discover the derivatives with strong anticancer activity.

\section{Supplementary Materials}

Supplementary materials can be found at http://www.mdpi.com/1422-0067/16/02/3980/s1.

\section{Acknowledgments}

The authors would like to thank the Ministry of Science and Technology, Taiwan (MOST 103-2320-B-039-027-; MOST 103-2738-M-039-001-; NSC 103-2911-I-002-303; MOST 104-2911-I-002-302; MOST 103-2325-B-039-008; MOST 103-2325-B-039-007-CC1), National Health Research Institutes (NHRI-EX103-10241BI), China Medical University (CMU103-N-05), and in part from the grant from Chinese Medicine Research Center, China Medical University (the Ministry of Education, the Aim for the Top University Plan) for financial support. We are also grateful to the National Center for High-performance Computing for computer time and facilities.

\section{Author Contributions}

Chi-Fen Chang performed experiments, analyzed data and wrote the paper; Yu-Lin Hsu, Chao-Ying Lee and Chia-Hua $\mathrm{Wu}$ performed experiments and analyzed data; Yang-Chang Wu revised the paper; and Ta-Hsien Chuang analyzed data and wrote the paper.

\section{Conflicts of Interest}

The authors declare no conflict of interest.

\section{References and Notes}

1. Boufford, D.E.; Hsieh, C.F.; Huang, T.C.; Kuoh, C.S.; Ohashi, H.; Su, H.J. Editorial Committee of the Flora of Taiwan, 2nd ed.; Flora of Taiwan: Taipei, Taiwan, 2000; Volume 5, pp. 795-796.

2. Wu, P.L.; Hsu, Y.L.; Jao, C.W. Indole alkaloids from Cephalanceropsis gracilis. J. Nat. Prod. 2006, 69, 1467-1470.

3. Wu, Y.T.; Hsu, Y.L.; Wu, P.L. Two indolotryptanthrin alkaloids from Cephalantheropsis gracilis. Heterocycles 2008, 75, 1191-1197.

4. Methyl 2-(aminocarbonyl)phenylcarbamate (5) is commercially available (CAS registry number 445285-93-8) from various sources, although no references are available in the scientific literature, according to Chemical Abstracts.

5. Cornforth, S.J.; Hitchcock, P.B.; Rozos, P. Isatin chloride: A phantom. Reactions of 2-(2,2-dichloro-2,3-dihydro-3-oxoindol-1-yl)-3H-indol-3-one. J. Chem. Soc. Perkin Trans. 1996, $1,2787-2792$. 
6. Takayama, H.; Matsuda, Y.; Masubuchi, K.; Ishida, A.; Kitajima, M.; Aimi, N. Isolation, structure elucidation, and total synthesis of two new Chimonanthus alkaloids, chimonamidine and chimonanthidine. Tetrahedron 2004, 60, 893-900.

7. Ghosh, I.; Zeng, H.; Kishi, Y. Application of chiral lanthanide shift reagents for assignment of absolute configuration of alcohols. Org. Lett. 2004, 6, 4715-4718.

8. Jao, C.W.; Lin, W.C.; Wu, Y.T.; Wu, P.L. Isolation, structure elucidation, and synthesis of cytotoxic tryptanthrin analogues from Phaius mishmensis. J. Nat. Prod. 2008, 71, 1275-1279.

9. Maskey, R.P.; Shaaban, M.; Grun-Wollny, I.; Laatsch, H. Quinazolin-4-one derivatives from Streptomyces isolates. J. Nat. Prod. 2004, 67, 1131-1134.

10. Deng, K.M.; Wu, X.Y.; Yang, G.J.; Qin, G.W. Alkaloids from Isatis indigotica. Chin. Chem. Lett. 1997, 8, 237-238.

11. Majumder, P.L.; Pal, S.; Majumder, S. Dimeric phenanthrenes from the orchid Bulbophyllum reptans. Phytochemistry 1999, 50, 891-897.

12. Majumder, P.L.; Majumder, S., Sen, S. Triterpenoids from the orchids Agrostophyllum brevipes and Agrostophyllum callosum. Phytochemistry 2003, 62, 591-596.

13. Valencia-Islas, N.A.; Paul, R.N.; Shier, W.T.; Mata, R.; Abbas, H.K. Phytotoxicity and ultrastructural effects of gymnopusin from the orchid maxillaria densa on duckweed (Lemna pausicostata) frond and root tissues. Phytochemistry 2002, 61, 141-148.

14. Das, B.; Takhi, M.; Srinivas, K.V.N.S.; Yadav, J.S. Phenolics from needles of himalayan Taxus baccata. Phytochemistry 1993, 33, 1489-1491.

15. Kazuma, K.; Noda, N.; Suzuki, M. Malonylated flavonol glycosides from the petals of Clitoria ternatea. Phytochemistry 2003, 62, 229-237.

16. Chen, K.S.; Chang, F.R.; Chia, Y.C.; Wu, T.S.; Wu, Y.C. Chemical constituents of Neolitsea parvigemma and Neolitsea konishii. J. Chin. Chem. Soc. 1998, 45, 103-110.

17. Wu, P.L.; Rao, K.V.; Su, C.H.; Kuoh, C.S.; Wu, T.S. Phenanthroindolizidine alkaloids and their cytotoxicity from the leaves of Ficus septica. Heterocycles 2002, 57, 2401-2408.

(C) 2015 by the authors; licensee MDPI, Basel, Switzerland. This article is an open access article distributed under the terms and conditions of the Creative Commons Attribution license (http://creativecommons.org/licenses/by/4.0/). 